In the hands of a 'Secular State': Meos in the aftermath of Partition, 1947-49

Rakesh Ankit

\title{
Loughborough University
}

\section{Abstract:}

This article focuses on unpacking the workings of the independent Indian nation-state in the region of Mewat in the aftermath of Partition violence, particularly the state's rendering of the Meo community there as a minority. This violence has been called a 'rite of political and territorial passage' and 'systemic ethnic cleansing' by scholars Shail Mayaram and Ian Copland, respectively. Building upon their works, this article focuses on state actors and details their 'rule of difference' in the treatment of Meos through the years 1947 to 1949 i.e. from their displacement to the conditions of their resettlement. This documentation is done by accessing the hitherto unused files of the Ministry of States, the Ministry of Relief and Rehabilitation, the Ministry of Home Affairs and the Prime Minister's Secretariat at the National Archives, and the post-1947 papers of Jawaharlal Nehru and Pandit Sunder Lal held at the Nehru Memorial Museum and Library.

\section{Keywords: Meos, India, Partition, Resettlement, Refugee, Violence}

\section{Introduction}

Historians have extensively documented the vortex of violence that gripped the British Indian provinces and Indian princely states in the build-up to and the aftermath of the Partition of India in 1947. ${ }^{1}$ This historiographical corpus can be divided into two hitherto distinct but 
increasingly overlapping categories of (a) partition literature recalling riots, refugees, relief and rehabilitation, ${ }^{2}$ and (b) the scholarship on the post-partition consolidation of successor dominion states centred around constitution, planning, republic and states reorganisation. ${ }^{3}$ This article, situated within this developing overlap, ${ }^{4}$ unpacks the workings of the independent Indian nation-state in the region of Mewat, particularly the manner in which the Meo community was marginalised in the aftermath of Partition violence there. This violence has been rightly called a 'rite of political and territorial passage' and 'systemic ethnic cleansing' by Shail Mayaram and Ian Copland respectively. ${ }^{5}$ It has been well-explored by Mayaram in terms of its 'objectification of the other and transformation of the self'.$^{6}$ It has been held up as an example of 'the further shores of Partition' by Copland. ${ }^{7}$ Complementing their works, this article focuses on the treatment meted out by the emerging Indian nationstate to the Meos through 1947-49 and attempts to catalogue their consequent minoritisation. This was achieved by a re-definition of the categories of nation and citizen, a re-configuration of the discourse of loyalty, a renewed commitment to communalised discrimination, and a reassertion of the metropolitan prejudices of the bureaucratic elite.

The emergence of a composite culture in the region of Mewat through medieval ages and its accompanying politicisation in modern times are well-established. While Mayaram showed the shaping of the Meos' 'Muslim Identity', ${ }^{8}$ Saurabh Bhardwaj has traced their 'Migration, Mobility and Memories'. ${ }^{9}$ Recently, Mukesh Kumar has brought out more contemporary aspects of the complex 'nature of Religious Identities', embodied by the Meos. ${ }^{10}$ Earlier, Majid Siddiqi had researched the multiple, 'interlocking' context of their popular, peasant rebellion against their princely rulers in 1932-33. ${ }^{11}$ This article extends their research by focusing on the newly independent Indian nation-state being ranged against this old community, with its history of anti-state resistance and marginality.. ${ }^{12}$ It adds further details to the former's difficulties in coming to terms with this composite space in the wake 
of Partition; a time of transition, still 'constituting some kind of an academic no-man's land'. ${ }^{13}$ It seeks to plumb the depths of its 'official mind' during a period of flux when the imperatives of state-consolidation, the ideologies of nation-building and the contingencies of Partition saw it further worsen the fractured social milieu of the Meos. Even as bloodshed subsided in the last days of the 1940s, a form of routine, state or bureaucratic, violence, ${ }^{14}$ emerged, causing a million pities of Partition, ${ }^{15}$ as state actors sought to unfeelingly impose their policies.

The article investigates the heartfelt charge that Maulana Abul Kalam Azad laid at Dr N.B. Khare, prime minister of Alwar and associated with both the Indian National Congress and the Hindu Mahasabha, 'aapne sitam kiya Alwar mein. Aapne Musalmaanon ko bahar nikaal diya [you committed an outrage in Alwar, you threw out the Muslims]'. ${ }^{16}$ Covering the period from May 1947 to May 1949, it is organised in five parts, preceded by a short prologue and followed by a short coda and conclusion. Each part seeks to provide the 'pure particular' around a thematic phase of the Meos' unsettled existence, scattered experience and wider displacement, and, their stock-taking by the state, for its provision of a 'Compact Area' for them. ${ }^{17}$ This accumulation is based on the documents available at the National Archives of India (NAI), from the Ministry of States (MoS), which was the nodal ministry for the treatment of Meos; the Ministry of Relief \& Rehabilitation (R\&R); the Ministry of Home Affairs (MHA) and the Prime Minister's Secretariat (PMS). These are supplemented by the Pandit Sunder Lal Papers and the post-1947 Jawaharlal Nehru Papers housed at the Nehru Memorial Museum and Library (NMML). Pandit Sunder Lal, ${ }^{18}$ along with fellow Gandhian social workers Acharya Vinoba Bhave and Mridula Sarabhai, ${ }^{19}$ was actively involved in the Phir Basao [re-settle] scheme for Meos.

These documents allow us access to the period from before mid-August 1947, when Meos were looked upon as agitators and rebels 'against the state' in Alwar, ${ }^{20}$ to after mid- 
May 1949, when the United State of Rajasthan was created and their return to their homeland was not considered 'practical politics' by many of those in power in New Delhi. ${ }^{21}$ As noted by Gyanendra Pandey, this was because by then the Meos of Mewat, along with 'the Momins of U.P. and Bihar [and] the Mapillas of Malabar' had been reduced to 'simply "Muslims"...fundamentally different and forever suspect'. ${ }^{22}$ This article attempts to throw light on this deteriorating relationship between the Meo community and the post-1947 Indian nation-state in five parts, each of which draw from different primary prisms of material. It threads together (a) eye-witness accounts of non-state actors (non-Meos as well as Meos), (b) reports of the Gandhian interlocutors who visited the affected areas, (c) statements of local police and revenue officials, (d) the higher bureaucracy's response to the situation on the ground and (e) the pronouncements of political leaders in highest positions, including the Prime Minister and his Deputy. In doing so, it adds to a picture of rupture of the Meos' social contract with a Hinduised state and society; what Mayaram termed the 'tense psychological moment of belonging/unbelonging to the Indian nation for Indian Muslims'.. 23

\section{Prologue}

Historically, the 'peasantisation and Islamisation' of the Meos in medieval ages was a long process of 'contestations and accommodations' ${ }^{24}$ on one hand and 'continuous resistance to various state formations' on the other. ${ }^{25}$ According to Mayaram, their self-perception centred on being ksatriya and one of their origin myths surrounded an early-eleventh century Sardar named Abdul Rahim Khan. Thereafter, they settled in the area around Gurgaon, Alwar and Bharatpur, which saw the emergence of a complex community that saw more communal unease as the colonial period started to draw to a close, with a growth of 'popular organisations' in these princely states and a growing crisis of governance, detailed by 
Copland. ${ }^{26}$ Moreover, as Pandey has remarked, in 1947, the 'regional, caste and occupational markers' by which Muslims had been formerly distinguished lost their significance. The composite identity of the Meos was also cut through in the determining aftermath of Partition and 'all of them were [seen] as open or closet Pakistanis'.${ }^{27}$ Evangeline Ingram, a Quaker social worker in Gurgaon for sixteen years and a member of the Friends Service Unit there, recalled that in early-March 1947, in a panchayat of Jats and other Hindus of Gurgaon, Alwar and Bharatpur held at village Hodal, it was decided that Meos, by virtue of their being Muslims, should be looted. In the then-polarised pre-partition context, it represented a culmination of the attempts by the kingdoms of Alwar and Bharatpur to craft a Hindu rastra, assisted by the social agenda of the Arya Samaj, from the 1920s and 1930s onwards and resisted by the Meos led by Kunwar Mohammad Ashraf. ${ }^{28}$

Post-15 August 1947, the rulers of Bharatpur and Alwar, as well as their families, courtiers and civil and police officials, began 'doing away with all the Meos, insisting that they were rebelling'. They were supported by the rulers of Jaipur, Jodhpur and Patiala, who 'sent forces to remove, shoot and kill them'. ${ }^{29}$ A number of Meos fled to Pakistan, while another large group went to Gurgaon, where they were harassed, looted and driven out by the police and military of the Indian Union. Some members of the local Congress party tried to help, and the Lady Mountbatten Fund provided them with a donation of Rs. 8810/- for three months. One such member was Pandit Harihar Lal Bhargava, advocate and member of the Phir Basao committee in Mewat, who lamented the fact that

in spite of the commitments of the [all-India Congress Committee] and of the Indian Union, orders are being passed in such a way that people instead of rehabilitating (sic) are being forced to vacate their lands. In Gurgaon district, where Muslims in lakhs are residing, orders have been passed by 
the DC [District Commissioner] that Meos, resettled in their vacated homes be ejected with aid of police. Similar orders have been passed in Alwar state...I fail to understand that now when the Indian Union wants all Muslims to return to their homes, action is taken in this manner. Every Muslim has a right to enter his home and have preferential rights than Western Punjab Hindu and Sikh refugees...Alwar and Bharatpur Meos are out of their homes for the last ten months and have no means of substance; when some thefts take place, the whole Meo community is blamed. ${ }^{30}$

Wazir and Rustam Khan, Abdullah and Allah Baksh, Ismail and Imam Khan, and Sulaiman and Bashir Ahmed were a handful of Meos, whose names and grievances made it to the officials' registers in spring 1948 and thus to the archives seventy years on. Their women, cattle, ornaments/jewels and crops had been attacked and captured, harassed and looted, by the States' military, with the Indian Union's police being either spectators or accomplices; even on occasion persecutors, but scarcely protectors. ${ }^{31}$ The Meos' pleas for help prompted social workers like Pandit Jiwan Lal, Pandit Bhargava and Munshi Ram Malik to tour the area in April 1948, along with Chaudhary Yasin Khan (President, All-India Meo Panchayat), and they reported to Sunder Lal and Vinoba Bhave. Their reports record the plight of the Meos at the hands of both officials and non-officials: the Bharatpur state military forcibly removing them and charging ransom money and the Gurgaon police registering false cases against them, alleging connections with the Communist Party of India. At the heart of it all was the following question: can/should Muslims such as Meos, who were forced to leave their homes in spite of their desire to stay in India, be treated as refugees or displaced persons and be given the same facilities as Pakistani non-Muslim refugees? ${ }^{32}$ Or, as the village revenue officials and local sub-inspectors were telling them in village after village in Alwar, 
Bharatpur and Gurgaon, having reduced their plural identity to that of a singular, homogenised 'ethnic other', ${ }^{33}$ that they had 'no right to live in the state' and 'should go to Pakistan'. After all, 'there was no Muslim officer from DC [District Collector] to patwari. Why were they staying here?' 34

\section{May 1947-March 1948: Performing Prejudice}

In his travels of about 220 miles in the area, Munshi Malik found only 'a few Jat villages displeased with Meos' rehabilitation' on Indian soil, but many more 'men in service [so displeased], because of personal bias'. Moreover, he saw 'Meos and their neighbouring Hindus happy in their homeland', but 'the Pakistani refugees in villages not satisfied'. Malik asserted that 'if the government considers the Meos as loyal citizens of the Indian Union, then it should see that each one of them is put in possession of his original home and land'. For Pakistan refugees, he recommended that 'they be rehabilitated in new lands, still vacant'. ${ }^{35}$ This was in direct opposition to the demand by 'substantial sections of the north Indian population, especially Hindu and Sikh refugees and those most directly affected by their influx, that north India or at least parts of it... should be cleared of Muslims: the latter should be sent to Pakistan, and the territory handed over to the Sikhs and Hindus'. ${ }^{36}$ Indeed, Rotem Geva has recently investigated 'Muslim minoritization' in Delhi and their 'ghettoization, resulting from ongoing struggles over Muslim houses,,${ }^{37}$ for the rehabilitation of Hindu and Sikh refugees there. Before her, Vazira Zamindar had shown the effects of the processes of Partition, put in place to make citizens of subjects in the national capital. ${ }^{38}$ The correspondence of Chaudhary Yasin Khan, arguably the most important leader of the Meos at this time, shows what they were enduring at the hands of state actors. Khan was a member of the Punjab Legislative Council and Assembly between 1927 and 1947. He had mobilised a 
major peasant movement comprising Meos, Jats and other caste groups in Alwar and Bharatpur in $1932 .{ }^{39}$ He was arrested on 27 April 1948 in Daryaganj, Delhi on suspicion of being a Communist, and was put under preventive detention. No charges were framed against him and no further claims were made. Yet, he remained in jail for a month. This is how he pleaded for his release in a representation to the District Magistrate:

I am not a Communist. I have never had any connection with the CP. I, along with many other leading social workers, have been helping the Meos in their rehabilitation since September 1947. The Meos of Gurgaon district along with those from Alwar and Bharatpur states staying in Gurgaon, are and will always be loyal to the Indian Union. They have no connection with Pakistan...The stay of Meos in Gurgaon is due to Mahatmaji's advice and the keen interest which he took in their case. My detention in jail is of no good to the government or the public. I assure you once again that I will continue to exert my influence with the Meos and see that they prove their loyalty to their Home Government by their deeds and that they will be friendly with their neighbours. Will you kindly order my release today and oblige? ${ }^{40}$

Khan worked under the guidance of Vinoba Bhave and was not the only Meo leader to be 'wrongly arrested'. Driven out of Alwar and Bharatpur states in end-May 1947, about three lakh Meos came to the adjoining Gurgaon district of the province of Punjab. From October 1947, pressure mounted on them to leave for Pakistan and Gandhi sent his lieutenants Sunder Lal and Maulana Hafizur Rahman, to assess the situation. Seeing his active interest, in early November 1947, the All-India Congress Committee passed a resolution recommending that 
evacuees return to their original homes, and the Union Government proclaimed this policy.. ${ }^{41}$ When Fateh Jung ka Gumbad was desecrated in Alwar, Nehru wrote to the Deputy Prime Minister Vallabhbhai Patel, who was also the Minister for Home and States ministries that the princely ruler be 'pulled up' for this 'disgraceful sacrilege' else 'that will reflect on the GOI [Government of India] also'. ${ }^{42}$ R. C. Hadow, of the British High Commission in Delhi, was visiting Alwar on 17 November, when he reported seeing a convoy of 80,000 Meos 'on their way to Pakistan'. The next day, he saw some 10,000 of them returning, having 'decided against going to Pakistan after all'. ${ }^{43}$ Subsequently, Mridula Sarabhai visited Gurgaon on 2-4 December and, eventually, Gandhi himself arrived and addressed a Meo gathering in Ghasera village, 45 kilometres south-west of Gurgaon, on 19 December. Calling them the 'backbone of India', he urged the Meos to stay back in a speech, echoes of which are still heard seventy years on. ${ }^{44}$

Gandhi's assassination in January 1948 is commonly held as 'the turning point in “communal” relations after Partition'. ${ }^{45}$ Yasmin Khan regards the situation after Gandhi's death as one of 'a major consolidation of power...through the selective use of the state apparatus, the strengthening of Nehru's authority', and 'the funeral and mourning rituals themselves as political events, widely shared and experienced by recently-emancipated postcolonial Indians'. ${ }^{46}$ However, prejudices among state officials and Congress politicians against Meos, equated with Muslims, held through the summer of 1948 and beyond, resulting in their widespread dislocation. Harihar Lal Bhargava, who shuttled back-and-forth between Gandhi, the Central Government and Gurgaon Meos from December 1947, carried stories of 'acts of terrorism' along the Alwar-Bharatpur-Gurgaon border. On 22 March 1948, Sobha Ram, then-Chief Minister of the newly formed Matsya Union, composed of the princely states of Alwar, Dholpur, Bharatpur and Karauli, visited the Meos in Gurgaon, assuring them of their imminent return to Alwar. ${ }^{47}$ Dr N. B. Khare's premiership had ended in February 
1948 and his departure had been accompanied by sanctions against the Rajas of Alwar and Bharatpur, who had been 'complicit' in Gandhi's assassination. ${ }^{48}$ Sobha Ram's assurance, however, was to be effected by the mandarins in the MoS and R\&R, who informed Harihar Lal that 'refugees from West Punjab were to be rehabilitated first and nothing can yet be said about Meos'. On the ground, compulsion and conversion continued through the summer of 1948, unless Meos obtained 'permits from the States Ministry'. 49

By May 1948, more than a year after their troubles had started, Meos could be divided into five categories: (1) those who never left their homes, regardless of the dangers, (2) those who were driven to Pakistan and desired return, (3) those who left but returned soon after, (4) those who left for other parts of India, (5) those who were driven to Pakistan but returned after a while, (5). It was the last three categories that bore the brunt of the discrimination by local panchayat, police and civil authorities, while those who never left their homes had to face the pressure of conversion. In the hands of the new state, as under the old princely order, Meos were charged simultaneously with being communalist, separatist, communists and coweaters, as the local officialdom and regional administration remained the same. ${ }^{50}$ On the other hand were petitions from Jats, Ahirs, Gujars, Mahajans and Thakurs of Kirdari and surrounding villages, which begged to 'certify' the 'excellent character and conduct' of their Meo neighbours and 'strongly recommend' their wish to return. Evangeline Ingram compiled a report for the Friends Service Unit (Gurgaon) on the 'situation in Mewat' at this time, which records these paradoxes and perversions well:

The local District Commissioner and Superintendent of Police are persons responsible for turning out Meos forcibly and they belonged to the West Punjab. Their attitude and mentality [are] unchanged. The local police organised two panchayats and wanted the Meos to agree by compulsion to 
stop cow-killing. The local officials are infuriated against local leaders and have arrested [them] under the pretext of being Communists...The Meos are returning from Pakistan and are not allowed to settle in their vacant houses. The district Congress president, Rao Gajraj Singh, was a Hindu Mahasabhaite and a recruiting officer in 1942 and opposed all Congress activities. He still holds that attitude of mind...Under the pretext of the East Punjab Evacuee Property Act, those Meos who resettled six months back on their lands and houses on the assurance of the government are forcibly ejected. Some Meos who resettled in Alwar on the assurance of the new Ministers are being forcibly ejected...Looting and murdering are the order of the day at the instigation of the Bharatpur military. In spite of declarations by the government, 6 months [later] not even a chaprasi out of Mohammedans has been employed. No loans or relief is provided to this population...In general, the attitude of the local officials in Gurgaon or these states are antagonistic towards this Muslim population...Meos love their motherland and are staying in spite of all provocation and persecution. Yasin Khan is the sole leader of the Meos and his people have great faith in him. He has advised [them] to join the Congress...He is the person who practised the sermons of Bapuji that the Meos should prefer death rather than go to Pakistan. ${ }^{51}$

With the sustained activism of social workers putting pressure on New Delhi, the administrations of Alwar and Bharatpur were forced to respond. K.B.L. Seth and S.N. Sapru, senior ICS Men sent as 'administrators' to these princely states, set out their positions in February-March 1948. Seth began by offering some numbers from the 1941 census, which 
had recorded 1.34 lakh Meos in Alwar state - a figure that might have increased to 1.40 lakh by August 1947. Out of these, barring the 30,000-50,000 who were converted and were thus able to stay back, the rest had left the state, but a small number of 10,000 had subsequently returned. Among the rest on the move, it was difficult to estimate how many had gone to Pakistan and how many remained in Gurgaon. Seth called for a three-fold conditional cooperation with New Delhi's policy to restore these latter to their homes/lands and, in doing so, provided the first glimpse of the workings of the 'official mind'.

Cultivable land belonging to about 18,000 Meos had already been distributed among about 9,000 refugees from Punjab, the NWFP and Sindh, with permanent hereditary rights. The Alwar government now felt it 'unfair and hard to deprive the refugees of the land', although it had been unfair on its part to allot these lands to the refugees in the first place. Second, it wanted to make a clear distinction between Meos who had migrated to Pakistan and those who remained in India. It had no objection 'to restore to the latter, as far as possible, the lands which they [had] held prior' to the disturbances. This did not however apply 'to those whose lands [had] been given to the refugees'. They were to get equivalent land elsewhere. As for the former group, Seth considered it 'extremely risky' to restore land to them. This was so not only because of the then-prevailing communal climate across north India, but also because of 'the attitude of the Meos' towards the refugees. Claiming that Alwar was near the Pakistan-India border - it is at least 450 kilometres away - Seth could not ignore the 'potential danger' of the existence of hostile Meos - returnees from Pakistan - in case of a conflict. Finally, Seth hoped that New Delhi would extend the necessary financial assistance for the resettlement of Meos, even though the problem was one of Alwar's own making. ${ }^{52}$

On the same day, Seth also wrote to the ministry of R\&R, making it clear that Meos' resettlement made it impossible for Alwar state to take in any more refugees. He asserted that 
the previous commitments had been made on the assumption that the Meo evacuees 'would not be coming back'. In a transparent pressure tactic, Seth remarked that only if New Delhi agreed that the Meos who were returning from Pakistan 'should not be given back their lands', would it be 'possible to absorb some more refugees'. ${ }^{53}$ This worried V. D. Dantyagi, Joint Secretary in the ministry, and he urged the MoS to prod Seth to take at least 40,000 refugees from the Kurukshetra camp. This was in view of the fact that over 1 lakh Meos had left Alwar, and perhaps 50,000 in Gurgaon, and based on the assumption that they would 'like to return'. ${ }^{54}$ One wonders how Seth would have responded to Syed Nasir Hussain Zaidi, a native landowner of Alwar state, who had been forced by the communal disturbances - in which many of his relatives were killed and all his belongings were seized - to flee to Karachi. Many Muslim landowners of Alwar state had fled in similar circumstances and were 'intensely willing to go back provided there [was] no further danger'. Writing to Nehru, Zaidi begged him to save them 'from being totally undone'. ${ }^{55}$

From the neighbouring Bharatpur, Sapru followed suit. Claiming that about 60,000 Meos had left Bharatpur as a result of 1947's disturbances, Sapru speculated that 'the majority of them [had] gone over to Pakistan'. As in Alwar, the land and houses of Meos had already been occupied by refugees from West Punjab but also 'other persons, who came in search of land from Jodhpur and Jaipur states and Rohtak and Delhi'. In this way, about 18,000 people had been settled and to Sapru, bringing the uprooted Meos back meant shifting this group, with consequent 'severe resentment'. Sapru went further than Seth, when terming the Meos a danger to state security, by pronouncing that they had 'not been known to be a peace-loving and law-abiding people'. Concluding that 'there was considerable feeling in the state against the Meos because of the past', Sapru advised the MoS 'to keep the Meos away for the present', notwithstanding New Delhi's declarations to the contrary. ${ }^{56}$ 
While Seth and Sapru were thus stalling, Meo leaders from Alwar and Bharatpur, Subedar Abdul Shakoor and Chaudhary Shamen Singh, were joining hands with Bhargava and Khan in taking their entreaties to Nehru. Barred from their homelands for nine months, driven out by the states' civil, police and military officials, and desirous of return under the declared policy of Nehru's government, they sought life and land, including for those compelled to leave for Pakistan but who 'wish to return and be loyal citizen[s]'. Pointing out that along with Punjabi refugees, 'Jats from Rohtak, Hissar and Gurgaon districts were given lands left by Meos', they demanded that the 3 lakh Muslims (Meos and others) staying in Gurgaon 'should not be sent to Pakistan but be set at liberty' to return to their homes. ${ }^{57}$ They were mistaken in approaching him though, for the man who mattered in these affairs was Patel. It was he to whom Sapru's and Seth's communications were brought and, in his reply to them, he was 'strongly of the view that for the time being only non-Muslim refugees should be settled in Bharatpur and Alwar' and 'Meos in camps in Gurgaon, whether of Gurgaon or of these states, should be settled on vacant lands in Gurgaon'. Patel did not see 'any prospect in the near future of Meos from Pakistan coming back'. In any case, nothing was to adversely affect 'the flow of non-Muslim refugees from Kurukshetra to Alwar and Bharatpur'. 58

\section{March-June 1948: Neither Citizen nor Refugee}

Patel had been put on the spot on the Meo question in the legislative assembly in mid-March, specifically on the issue of the increasing number of skirmishes between Meos residing in

Gurgaon district and villagers on the adjoining Bharatpur territory. ${ }^{59}$ Enquiries from Seth and Sapru had thrown light on the peculiar bind that Meos and refugees found themselves in. The heart of the matter was the Rabi crop, which the Meos had sown before they had to leave 
Bharatpur. Now, these crops, claimed by them, were being cut/reaped by refugees. Senior police officials were requesting their civil service superiors to decide 'whether this crop [belonged] to the Meos, the State or the Refugees'. Instead, Seth was occupied with examining proposals for establishing Home Guards in the Matsya Union and creating special armed police for border villages. Lamenting that both the strength and the discipline of the police force in Alwar and Bharatpur was unsatisfactory to patrol the twenty-twenty-five miles long border with Gurgaon, Seth sought to shift the responsibility to the shoulders of the District Magistrate (DM) and the Superintendent of Police (SP), Gurgaon, 'whatever the respective rights of the contesting parties'. ${ }^{60}$

Bharatpur's Inspector-General of Police (IGP) as well as the SP, however, were clear that 'the question of the ownership of the crop [had] to be decided first', before attempting such solutions as calling military troopers. ${ }^{61}$ All in all, 92 such cases of raid, theft, arson, loot and killing were registered between August 1947 and March 1948 against Meos, almost all belonging to Bharatpur and now forced to reside in villages on the border in Gurgaon district. Officials, with the exception of Gopal Das, approached the situation in isolation, as a law and order problem created by the 'Meo menace'. ${ }^{62}$ Continuing with the colonial 'construction of Meo criminality, ${ }^{63}$ as described by Mayaram, they did not consider the immediately preceding context of the Meos' enforced deprivation followed by their enforced proximity to their land, labour and its riches. Alongside, there was another side-show to this unfolding story, which throws more light on the harsh circumstances and hard sentiments, prevailing around Meos.

Over 8-10 April 1948, Muslim Rajputs from village Bhungara Thapar and Muslim Ranghars from village Mungara Thatar of Alwar state had seen about 100 individuals being evacuated in a military truck bearing a Pakistani plate and this had caused a 'sensation' in the area. ${ }^{64}$ Sher Ali, a resident of Bhungara, had a son-in-law in the Pakistani army, Jamadar 
Wali Mohammad, who was organising this escape for his relatives and others. Quite apart from procedural issues, the more disturbing thing was that it was claimed that these residents of Bhungara Thapar had 'voluntarily' changed their religion during the disturbances. About half of the Muslim population in this area had left earlier and those remaining had sought to 'embrace Hinduism'. Clearly, given their willingness to go to Pakistan, their conversion had been anything but 'voluntarily'. Yet, the local Nazim, the Station House Officer, the SP and the DM insisted on it, to imply illegality 'on the part of Pakistan personnel'. They claimed that this enraged Hindu residents, thus ultimately 'jeopardising' the lives of the remaining Muslims. ${ }^{65}$ This manner of 'blame displacement' was often used to anticipate the breach of 'public peace'. ${ }^{66}$ The Ministry of R\&R stated that if these converted persons wished 'to go over to Pakistan', they would not object, ${ }^{67}$ as the two Prime Ministers had recently decided in regard to such forced conversions. The MoS, on the other hand, was bullish:

The policy in question was to be applied to the recovery of converted persons in the East Punjab states... The point at issue is the illegal and unauthorised use of a military truck by certain Pakistan personnel for the evacuation of their converted relatives...If this sort of thing were to be condoned, there is every danger of a communal frenzy. ${ }^{68}$

In other words, for the MoS, if some Meos they had relinquished their Muslim identity in exchange for the right to life, they must live out that life in India as Hindus. Those who had resisted this deal of either safaya [cleansing] or suddhi [conversion] and were therefore on the run from Alwar and Bharatpur, must leave for Pakistan. Non-Muslims, on the other hand, especially if they were refugees from Pakistan, had the Indian nation and the state to themselves. As Patel put it to a Hindu correspondent from West Punjab, 'you can rest 
assured that the Hindus and Sikhs of Pakistan cannot be considered as aliens in India'.${ }^{69}$ Only if there was 'room left' after their rehabilitation, could the resettlement of Meos be considered. That too, if, till then, they stayed put in Gurgaon. ${ }^{70}$ Describing their state as another episode in 'twentieth-century history of nation-state formation, competing nationalisms and competing proselytism', Shail Mayaram has argued that 'few Meos were interested in Pakistan, in Urdu or in the Muslim League, but their choices were few; to die, convert or cross the border'. ${ }^{71}$

On the other hand, as Mridula Sarabhai was informed, non-Muslim refugees arriving from Pakistan were to be settled in Bharatpur and Alwar, while Meos returning from Pakistan were to be settled in Gurgaon; close to but not on their former homelands. ${ }^{72}$ After all, they were evacuee Muslims requiring restoration and not non-Muslim refugees requiring rehabilitation, and the 'restoration of evacuee property [was] subject to rehabilitation requirements'. Despite the fact that the agricultural property had been evacuated under duress, Lall and others did not think it possible to permit its 'restoration' to Meos. ${ }^{73}$ And yet, all-powerful as the MoS seemed, there were voices in the upper echelons of the state apparatus to at least contest it. C. M. Trivedi, Governor of East Punjab, emerged as one such voice. He proposed to K. C. Neogy, Minister for R\&R, as well as the Prime Minister that of the two and a half lakh Meos, who stayed behind, 80,000 belonged to Alwar and Bharatpur and their resettlement was therefore the responsibility of the Matsya Union. Trivedi was responding to the MoS's position that these Meos should be settled in Gurgaon, while an equivalent amount of land should be reserved in Alwar and Bharatpur for Hindu and Sikh refugees. Further, he was informed that the Matsya Union wished 'to allot the lands abandoned by the Meos to local residents', and not to refugees. ${ }^{74}$ Sobha Ram wanted to reserve 50,000 acres out of the 2,00,000 acres left behind by Meos 'for redressing internal inequalities of tenures and holdings'. The remainder, if not taken up by non-Muslim refugees, 
was to be sold or let to people from inside or outside Matsya Union. Trivedi suggested that this 'evacuee' land should be used for resettlement of all Meos in India. ${ }^{75}$

Patel swatted this suggestion aside, when he met a deputation from the Matsya Union ministry a week later. He told them that he was 'entirely opposed' to the return of Muslims to Alwar and Bharatpur and instructed them that if any representations like Trivedi's, were made to the Matsya Union, they should say that 'it was for the States Ministry' to decide. The Matsya Union's position was that 'in place of Muslims', it would accept refugees. ${ }^{76}$ Faced with such intransigence, Nehru finally entered the fray directly and read the following riot act to the mandarins in the MoS:

It is the decided policy of the GOI that Muslims who had left their houses temporarily owing to disturbed conditions, for other parts of India, are entitled to have their property restored to them provided the Custodian considers it justified. The position taken by [Matsya Union] that the entire agricultural property evacuated by the Meos was required for the rehabilitation of refugees from Western Pakistan, and therefore it was not possible to remit its restoration to them, would not be defensible. We may not be able to restore the entire property to the Meos in Bharatpur and Alwar, because during their absence some other interests might have been created in part of the property and we might find it difficult to evict the parties that have acquired such interests, but after excluding such property and also excluding some other that might have already been promised to refugees, it should be possible to return the rest of the land provided the local inhabitants do not object. ${ }^{77}$ 
It was clear that Nehru and Patel were on a collision course on the question of "the early disposal of the Meos squatting in Gurgaon'. The MoS coolly informed the Prime Minister's Secretariat that 'the policy of the States Ministry has been accepted by the Ministry of R\&R'. ${ }^{78}$ Nehru's allies in this matter were a Maulavi in Alwar and a Maulana in Delhi. Maulavi Mohammad Ibrahim, representing the Meos of Alwar, came to see him on 31 May 1948 and requested that the one and a half lakh Meos of Alwar and Bharatpur, residing in Gurgaon, should be resettled in these states, as the lands evacuated by them had been redistributed among local and neighbouring Jats and not evacuees from Pakistan. In Alwar, Ibrahim charged, there were 11 lakh bighas, which had been only partially allotted to nonMuslim refugees from Pakistan. He further claimed that non-Muslim evacuees from Pakistan were not all willing to settle on this harsh, dry land, which would go to waste in the upcoming cycle of monsoon. Finally, Ibrahim believed that the Matsya Union ministry and administration would be 'willing to take back the Meos', if the States Ministry told them to do so. ${ }^{79}$ In Delhi - Education Minister Abul Kalam Azad - knew better. He communicated directly with the Deputy Prime Minister's powerful advisor on princely states, V. P. Menon, asking him to permit those Bharatpur and Alwar Meos, 'who went to Pakistan but have now returned and are anxious to settle down in their old homes', as well as 'those Meos who took refuge in Gurgaon', to do so. He too had been 'given to understand' that the people as well as the administration of both the states were amenable to their resettlement. ${ }^{80}$

With pressure mounting thus, Neogy visited Patel in Dehradun, where the latter was recovering from his heart attack, to discuss the matter. Patel stuck to his previous opinion that all those Meos who belonged to Alwar and Bharatpur and had left for Gurgaon should be given facilities for rehabilitation there and that, in turn, 'those non-Muslims entitled to rehabilitation facilities in Gurgaon would be given corresponding facilities in Alwar and 
Bharatpur'. Meos who had migrated to Pakistan and have returned should be put into a camp and be removed to Pakistan as soon as arrangements could be made. Neogy understood from Patel that 'it was a mistake to have retained any Meos in Gurgaon and a demand for the removal of all the Meos in Gurgaon district to Pakistan would be justified. In any case, no Meo should be allowed to migrate from Pakistan to India'. ${ }^{81}$

\section{June-August 1948: Towards a Fact-Finding Committee}

Faced with this united front of the MoS and R\&R, Nehru took away the responsibility for the Meo question from Neogy's hands and assigned it to the Minister without Portfolio, N. Gopalaswami Ayyangar. The latter reached out to K. B. Lall, Administrator of the Matsya Union, for information about the situation on ground. There the Meos, prevented from returning to Alwar and Bharatpur but staying just across the border in Gurgaon, were starting to take matters into their own hands and enter the territory of their former home-states. This led both Gurgaon and Matsya Union authorities to employ heavy-handed methods of army deployment. Lall's informative reply to Ayyangar's query is quite illustrative of the workings of the Matsya Union ministry and the MoS, in the summer of 1948. It is also remarkable for its casualness towards the plight of the one and a half to two lakh Meos. On its part, the Matsya Union had moved on, regarding 'the entire agricultural evacuee land as reserved for the rehabilitation of refugees from Western Pakistan'. ${ }^{82}$

Nevertheless, as alluded to above, many Meos were managing to 'infiltrate' into the vacant areas on the borders of Gurgaon. Terming their entrance into their old homes and lands as an 'illegal occupation of evacuee property', Lall estimated their number at 8,00010,000. Incredibly, they were being 'persuaded to move back to Gurgaon'. ${ }^{83}$ There were also those 15,000 Meo converts who had not migrated and were holed up in the Lachhmangarh 
tehsil of the Union. Lall was clear that if the whole of the evacuee land in Matsya was not required for the use of agriculturalist refugees, then the Matsya Government wished to dispose of a portion of it to local cultivators, with a view to easing off the pressure on the soil and to 'redressing the gross inequalities' in the prevailing system of land tenure. If, instead, New Delhi pressed it to resettle the Meos, 'who had continued to hang about Gurgaon', the Matsya Government would grudgingly do so, on 'a portion of the evacuee land'. ${ }^{84}$

Meos were already yesterday's problem for the Matsya Union, whose current pursuit was 'to "grow more food" and to prevent evacuee land from becoming uncultivable'. ${ }^{85}$ It was endeavouring to lease out evacuee land to locals for the Kharif season on very low rental. This action was, naturally, being resented by Meos, who, rightly, feared that their lands would thus be 'totally lost to them'. Distressed since pre-August 1947 and disappointed postAugust 1947, they were now getting desperate and were reported to be 'contemplating, by direct or indirect means, to hamper cultivation' by the lessees. To the amoral state apparatus, this constituted 'unlawful activities on the part of Meos', ${ }^{86}$ an obstacle to the 'grow more food' campaign, with adverse effects on the entire programme to rehabilitate refugees.

Matters came to a head at the eighth meeting of the Joint Rehabilitation Board held on 25 June 1948. Nehru presided over the usual galaxy of ministers and mandarins, with the exception of Patel, who was represented by M. K. Kirpalani, Joint Secretary (MoS). Interestingly, Vinoba Bhave and Sudhir Ghose, two Gandhian social workers who were involved with the Meos' struggle, were present. The resettlement of the Meos, which was item number three on the agenda, was taken up first. It was declared that it was 'GOI's responsibility to resettle Meos who belonging to areas in the Indian Union had left their homes and lands but had either not left the Union or having left it have already returned to it'. ${ }^{87}$ They were to be resettled 'somewhere in the area comprising the Gurgaon district of East Punjab and the states of Alwar and Bharatpur in the Matsya Union'. Second, a 'fact- 
finding' committee comprising three persons consisting of a representative each of the Ministry of R\&R, East Punjab and Matsya Union was to be appointed. It was to report by 15 July 1948. It was to record the number of Meos present in the area, enumerate those who belonged to the Matsya Union, and those who had gone over to Pakistan but had returned and, lastly, determine the land available for allotment in East Punjab and Matsya Union. Pending this report, it was allowed that 'leases for the next crop may be offered on a purely temporary basis to some Meos, both in Gurgaon and the Matsya Union'. Finally, it was accepted that the 80,000-10,000 Meos who had 'already infiltrated into the Matsya Union need not be ejected'.

These decisions clearly bore the stamp of the Prime Minister, who requested Mohan Lal Saksena, the new Minister for R\&R, to see that the fact-finding committee keeps 'in close touch with Vinoba Bhave'. Admitting that he was 'rather afraid of purely official committees' because they had 'a tendency to view things from an office and to ignore the human factor of the situation', Nehru reminded Saksena that the Meo question was one matter that 'though not big in itself', involved 'important principles and may lead to far reaching consequences'. Finally, to the Prime Minister, there was 'a definite connection between this business of our dealing with Meos and the Kashmir situation'. ${ }^{88}$ Meanwhile, when informed of Nehru's decisions, Patel was 'not in favour of giving lease of lands to Meos for the Kharif crop', for its potential of 'misunderstanding, alarm and trouble'.. ${ }^{89}$ His heart was stout enough to survive both its recent seizure as well as sentiments like those expressed by the Meos of nine villages of Kishangarh Nizamat in Alwar in a telegram to him:

We have been throughout in India. Never went to Pakistan. Moved out of Alwar state for 1 month due to disturbances and fear of death but lived in Gurgaon district villages. Returned back in our villages thence and are 
living for the last 6 months. No land with us so far allotted for maintenance.

We, Biswedars, have always been cultivating land. Have always been loyal and will be loyal in future. Beseech justice. ${ }^{90}$

Patel's disapproval delayed the formation of the fact-finding committee, which received its instructions on 30 July 1948, at the ninth meeting of the Joint Rehabilitation Board. It was directed to come up with 'a definite scheme for the resettlement of displaced Meos now in Gurgaon district in a compact area on the borders of the Gurgaon district and the Matsya Union, the area being wholly in Gurgaon/Matsya or contiguous', on the basis of a census of Meos. As the fact-finding committee got down to work, some of the first relevant albeit official and thus conservative figures started to emerge. At the outset, it appeared that the number of persons to be rehabilitated was 60,230 (persons who evacuated Alwar and Bharatpur for Gurgaon) + 1,812 (members of families partially migrated who stayed in India throughout and members of families partially migrated who have since returned to India) = 62,042 persons. The land required, based upon a rough average holding per head that Meos generally had, was about 1.5 lakh acres. Over 4 lakh acres was reportedly available in Matsya Union and over a lakh in Gurgaon. The figure of 62,042 was reached by estimating Meos in Alwar, Bharatpur and Gurgaon (based on 1941 figures + percentage increase) before the exodus i.e. 4,01,596. This number had been calculated in 1947-48 as follows: ${ }^{91}$

\begin{tabular}{|l|l|l|}
\hline \multicolumn{2}{|l|}{ Meo Census, 1948} \\
\hline A & Remaining in India throughout as Muslims & $1,82,838$ \\
\hline A.1 & Persons who never left Alwar and Bharatpur & $1,22,608$ \\
\hline A.2 & Persons who left Alwar and Bharatpur for Gurgaon & 60,230 \\
\hline B & Members of families partially migrated, who stayed in India & 4,294 \\
\hline
\end{tabular}




\begin{tabular}{|l|l|l|}
\hline C & Members of families partially migrated, who returned to India & 9,556 \\
\hline D & Remained in India as converts & 11,823 \\
\hline E & Total number who remained in India (A+B+C+D) & $2,08,511$ \\
\hline F & Migrated to Pakistan and not returned & $1,93,085$ \\
\hline & Total Number of Meos $(\mathbf{E}+\mathbf{F})$ & $\mathbf{4 , 0 1 , 5 9 6}$ \\
\hline
\end{tabular}

This exercise in cold calculation was in stark contrast to the heated episodes on the ground, now increasing in frequency, with the army stationed at Bharatpur getting involved. The commandant there sent an intelligence report that compiled well 'the competing and conflicting aims of local agriculturalists, local Baniyas, refugees, Pattedars and Meos' that had produced 'a problem of considerable complexity'. The conclusion was unmistakable: 'in the absence of a definite clarification of the Government policy regarding the Meos question, it is impossible to check the entry of the Meos, who are being invited by vested interests, which is becoming a cause of corruption'. ${ }^{92}$

Non-co-operative and unprincipled tehsildars, demanding revenue officials and police constables, opposing view-points within the central government, an uncertain DM, a highhanded army, local lalas and corrupt patwaris coordinating, collecting sums and promising resettlement to the Meos from Gurgaon - all had contributed in a surreptitious settlement of Meos in certain border villages. This matrix was causing considerable trouble for the Matsya Union ministers and administrators. Besides, there were the social workers and organisations, who might appear as a problem to various parts of the state apparatus, but to the Prime Minister, they were his prime informants. His main point remained that the 60,000 Meos, belonging to Alwar and Bharatpur, in Gurgaon 'should go back' even though only 1,34,000 acres of 'rather inferior land' was left over, from their old possession of 4,00,000 acres. Out 
of this, 1,16,000 acres had been 'temporarily leased' to the refugees and another 1,50,000 acres had been similarly given 'to local people... to avoid the land lying uncultivated'. 93

In early-August 1948, Nehru received a letter from the journalist B. Shiva Rao. It drew upon the eye-witness account of another, Dr Sivakamu of Women's Hospital, Alwar to report that while the government was thinking of sending Meos back to Alwar, those who were actually there were being 'driven out'. ${ }^{94}$ Several groups of Meos walking on the AlwarGurgaon-Delhi highway had told Dr Sivakamu that they were being driven out of their homes to Pakistan: 'the police and the soldiers tell us, your home is in Pakistan and these lands are for the Hindus. If you do not go away, we shall drive you with our sticks'. Ironically, they had returned to India, from Pakistan, relying on Nehru's and Gandhi's assurances that they could do so safely. Shiva Rao could not resist the jibe that large tracts of land were lying fallow because the Punjabis did not know 'how to cultivate these lands without water', ${ }^{95}$ as against the Meos, who knew Mewati soil but had been repeatedly removed from it.

While these turf-wars continued, Vallabhbhai Patel sent a long note to Nehru on the above-mentioned decisions. Beginning with the questionable claim that 'the Meos [did] not belong to the category of those who had left their homes temporarily for another place in India', Patel further stated that 'they had left their homes for good and were fully resolved to leave for Pakistan'. He asserted was that 'the main difficulty' in regard to return of Meos to Alwar and Bharatpur was 'the law and order problem'. He felt that 'the return of Meos, even in comparatively small numbers, would upset the whole non-Muslim population of Alwar and Bharatpur' as Meos had never been a 'peaceful section of the population'. They had the 'upper hand' in inter-communal feuds and 'even in the last disturbances', they took the law into their own hands 'with a view to aligning themselves with the Muslim League and establishing for themselves a Meoistan'. Patel therefore insisted that it was 'unwise and inappropriate' to accentuate the law and order problem by sending these Meos to 'hostile 
surroundings'. He claimed that the rulers of Alwar and Bharatpur had done their best to protect the Meos, and on this basis assumed that 'if these Meos left, they did so because their loyalties were elsewhere and because they did not wish to face the revenge and anger of the population, whom they had wronged'. ${ }^{96}$ As The Statesman had commented on 5 October 1947, 'how were the Muslims of India to prove their loyalty when the very act of fleeing in fear from their homes was interpreted as a sign of disloyalty and extra-territorial attachment?' ${ }^{97}$ Patel's conclusion was that

...grievance and bitterness of that wrong [persisted] in the areas ravaged by Meos and in view of the population being either local or refugee or mixed, the return of Meos to their old homes would be fraught with serious risk. Nor would it be in our interests to force Meos back into their homes at the points of bayonet... ${ }^{98}$

\section{September-December 1948: Carving out a 'Compact Area'}

Nehru and the cabinet decided on 1 September 1948 to wait for the report of the fact-finding committee and an accompanying scheme for the resettlement of the displaced Meos in a compact area on the borders of Gurgaon district and the Matsya Union. Meanwhile, the process of settling the Meos in Gurgaon district and the adjoining areas of the Matsya Union was to proceed and it was presumed that the States Ministry was taking action to implement it as far as the Matsya Union was concerned. ${ }^{99}$ On 15 September 1948, the committee consisting of N.C. Shrivastava, K.B. Lall and Tarlok Singh reported the following figures on the basis of the above-mentioned census of Meos taken in July 1948: 


\begin{tabular}{|c|c|}
\hline Meo families in Alwar, Bharatpur and Gurgaon & 19,525 \\
\hline \multicolumn{2}{|l|}{ Alwar } \\
\hline Number of Meo families & 6,846 \\
\hline Officially verified landholdings & 1,758 \\
\hline Area officially claimed & 26,754 acres \\
\hline \multicolumn{2}{|l|}{ Bharatpur } \\
\hline Number of Meo families & 5,940 \\
\hline Officially verified landholdings & 2,126 \\
\hline Area officially claimed & 27,807 acres \\
\hline $\begin{array}{l}\text { Area in Alwar and Bharatpur required on behalf of } \\
\text { the displaced Meos }\end{array}$ & $\begin{array}{l}\text { 95,082 acres ( } 41,804 \text { acres in Alwar, } \\
53,278 \text { acres in Bharatpur) }\end{array}$ \\
\hline $\begin{array}{l}\text { Area in Alwar and Bharatpur already allotted to } \\
\text { refugees }\end{array}$ & $\begin{array}{l}39,932 \text { acres }(26,643 \text { acres on lease, } \\
\text { of which } 19,000 \text { acres had been held } \\
\text { earlier by Meos) }\end{array}$ \\
\hline \multicolumn{2}{|l|}{ Gurgaon } \\
\hline Number of Meo families & 6,739 \\
\hline Area abandoned by Meos & $\begin{array}{l}\text { 37,321 acres in Nuh tehsil and 43,849 } \\
\text { acres in Ferozepur Jhirka }\end{array}$ \\
\hline Area needed for restoration to Meos & $\begin{array}{l}5,490 \text { acres in Nuh and 8,371 acres in } \\
\text { Ferozepur Jhirka }\end{array}$ \\
\hline Area available & 24,987 acres \\
\hline
\end{tabular}

While outlining its scheme, the committee emphasised the need for an early settlement, in time for sowing Rabi crops. It was conscious that, as temporary allotments to refugees had already been made till the end of Rabi 1948-49, the two schemes - refugee rehabilitation and Meo restoration - had got intertwined. Thus, permanently resettling Meos in Alwar and Bharatpur meant relocating refugees and it appeared that sufficient area was simply no longer available. On the other hand, a temporary settlement of Meos was possible for Rabi 1948-49 in Nuh and Ferozepur Jhirka regions of Gurgaon in the free land $(24,987$ acres) and that portion of leased land (21,000 acres) already held by the Meos, who had been 
residing there since the disturbances. Moreover, 13,315 acres were available in the Tijara and Pahari tehsils of Alwar and Bharatpur, which were contiguous to Nuh and Ferozepur Jhirka. Taken together, these lands amounted to 59,302 acres, a 'compact area' on which the displaced Meos could be settled. In effect, this meant that four-fifths of the displaced Meos were to be settled in the villages of their dislocation and were not to be sent back to their original homes. The committee claimed that the Nuh and Ferozepur land was better in quality than their original holdings in the dry lands of Alwar and Bharatpur. For the remaining onefifth, twenty villages in Tijara (Alwar) and twelve villages in Pahari (Bharatpur) were to be provided. ${ }^{100}$ The Joint Rehabilitation Board met on 24 September to consider these proposals and decided that the

displaced Meos from the Matsya Union and Gurgaon district who remained in the Indian Union or who, having left it, returned and been included in the census, be given temporary allotment up to the end of Rabi 1948-49, 45,987 acres of cultivated land in the Nuh and Ferozepur Jhirka tehsils of Gurgaon district and 13,315 acres of cultivated land in the Tijara and Pahari tehsils of the Matsya Union, immediately adjoining Nuh and Ferozepur Jhirka.

Further, 'in view of the inadequacy of information regarding the quality of land in the Matsya Union and the insufficiency of the area immediately available', each landholder was to get three-fourths of his verified holding in Matsya i.e. one acre of well-irrigated land was to be taken as equivalent to one and a half acres of unirrigated land. This ad hoc evaluation was, however, not intended to prejudice the final assessment of land in Matsya Union and the permanent allotment of land outside Matsya Union. Finally, the fact-finding committee was directed to prepare a scheme for permanent settlement for displaced Meos to take effect from 
Kharif 1949. However, even this permanent allotment was not to happen in Alwar and Bharatpur, from where an area of 50,000 acres of cultivated land was to be made available for immediate temporary allotment to refugees from East Punjab. This area was 'on account for East Punjab refugees', but the question of how much land was to be made available in the Matsya Union for allotment to refugees selected by the East Punjab government was to be considered at the time of permanent settlement of Meos in Gurgaon i.e. East Punjab.- ${ }^{101}$

With the policy decision seemingly made, the officials were keen to implement and entrench it. K. B. Lall, at the Matsya Union, was first in instructing his officers to lease out 13,350 acres of cultivable land in Tijara and Pahari tehsils for a year. The irony, as Lall himself noted, was that there were 'no refugees from East Punjab requiring rehabilitation facilities in Matsya Union', and the latter had merely been asked 'to reserve 50,000 acres of land for refugees from West Punjab in lieu of the area to be allotted to our Meos in the Gurgaon district'. Matsya's Meos largely remained in Gurgaon, West Punjab's refugees largely remained in East Punjab, and the former's land was reserved for the latter's future use. ${ }^{102}$ Some, like Patel's influential secretary, V. Shankar continued to remain restive, having noticed that the Rehabilitation Board had included 'Meos who had returned from Pakistan' in the plans. Shankar challenged this, as the previous position had referred only to Meos who had left Alwar and Bharatpur, but not those who had 'left for Pakistan'.. 103 Shankar wanted the MoS to look into this and drew the attention of the Ministry of R\&R. The East Punjab government was complaining that the Matsya Union had not transferred the stipulated 50,000 acres of land for allotment to Punjabi refugees, while the East Punjab government had allotted land to the Meos of Matsya Union. According to the terms of evacuee property arrangement in the two Punjabs, the area allotted to Punjabi refugees, who owned land in Pakistan, was to be carved from these 50,000 acres. ${ }^{104}$ 
A surprised Lall replied that by end-October it was 'too late for refugees to prepare for Rabi sowings', and that East Punjab had not made any requests either. He claimed it was 'too late to talk in terms of temporary allotment' but promised to set apart 'an equivalent area of land in Matsya Union for the rehabilitation of refugees of Punjabi extraction, who would otherwise have been settled in Gurgaon district, in the final resettlement scheme. ${ }^{105}$ Unconvinced, the East Punjab government continued to press. ${ }^{106}$ Lall however asserted that since approximately 27,000 acres of land had already been allotted to Punjabi refugees in Alwar district and an equal area in Bharatpur district, the claim of the East Punjab government had already been met.. ${ }^{107}$ This 'staggered programme', as Ian Copland called it, ${ }^{108}$ of reluctant rehabilitation can scarcely be called either an assertion of Prime Ministerial authority or an acknowledgement of Gandhi's wish for the Meos. Smothered by a stalling bureaucracy and supported by non-officials like Sunder Lal, Bhave, Sarabhai and Ghosh, Nehru had reached out within the Congress Working Committee to President Rajendra Prasad. Patel's response to Prasad on that occasion indicates well the intensity and personal impress with which the Deputy Prime Minister was determined to hold his hard-line approach. In the face of such intransigence, as follows, the Prime Minister had little alternative but to accept whatever assurance Patel was agreeing to:

I am not aware of any promise which Gandhiji made. I am sure he could not have given any promise about resettlement of Meos in the States. I had long talks with him on this question and our policy then was not to interfere with internal administration of the States. It was only after his murder that we dared to interfere in these States...I have no hesitation in saying that any other policy might well result in a disaster similar to the one which cost us Gandhiji's precious life. I see no reason why there should be any hurry 
about this matter and I do not appreciate the reason why this matter should come before the Working Committee...I would advise postponement of consideration of this question...If however postponement is not considered possible and any decision to reverse the existing policy is taken, I am afraid I will have no alternative but to resign from the Working Committee.. ${ }^{109}$

\section{November 1948-March 1949: 'Further Shores' of Meo's Displacement}

Around this time, away from this bureaucratic wrangling and political battle of wills, occurred an episode that shows how far were the Meos displaced. From the recently annexed princely state of Hyderabad, J. N. Chaudhuri, the military administrator, wrote to M. K. Vellodi in the MoS that approximately 6,500 Meo refugees of Bharatpur and Alwar states, who had taken shelter in the Hyderabad state in the disturbances of 1947, were expressing 'reluctance' to go back to their homes. This was in contrast to Muslim refugees from other areas such as the Central Provinces and Berar, the Madras province and the princely states of Gwalior and Mysore. They were insisting on being 'allowed and enabled to go to Pakistan' or, failing that, 'desired a safe passage to Bombay from where they said they would spread out in the Indian Territory'. Chaudhuri did not want them to move to Pakistan, for - apart from logistical difficulties - he feared negative publicity about the plight of Muslims in Hyderabad and the Indian Union. ${ }^{110}$

At the MoS, the junior Ganesan felt that it should not be difficult for the Matsya Union to take back these 6,500 Meos by allotting some additional land.. ${ }^{111} \mathrm{~V}$. Shankar, however, refused to consider this, citing refugee dislocation, law and order, 'enough claimants for land' and the Meos' unwillingness to return. He supported sending these people to Pakistan and 'in the meantime to keep them where they are'. ${ }^{112}$ On 19 November 1948 , in 
an audacious move, a deputation of Meos waited on Patel in Jaipur, who asked them to submit their grievances in writing. Mohammad Mian, secretary of the Jamiat-ul-Ulema-iHind, did so and it makes for difficult reading:

We know that Sardar Sahib is a man of determination and does what he says. The Meos have been suffering now for more than one and a half years. They are loyal citizens of Indian Union and had repeatedly claimed their loyalty to their mother country in the presence of Mahatma Ji. Their nonMuslim neighbours are prepared to welcome them back. They should be rehabilitated in [the] unpopulated villages of Alwar and Bharatpur. Prajamandal and local Hindus are prepared to help this. Though the GOI [has given] all assurance and satisfaction to the Meos but the behaviour of the police officers is such that Meos feel much disgusted. They are being beaten very badly and are being asked to go to Pakistan and, at the sweetwill of police officers, searches are made. Even Congress and Jamiat workers are the victims of police anger. Madrasas are being forced to close. Juma Masjid, Gurgaon, is in possession of the refugees. This mosque at least may be vacated, and its possession restored to Muslims. ${ }^{113}$

Patel was, however, saying something entirely different to his officials. He had first asked the Ministry of R\&R to approach Pakistan to accept the Hyderabadi Meos. It demurred, reminding Patel that Pakistan had only agreed to exchange the populations of East and West Punjab and had already protested against Muslims from Delhi, Alwar and Bharatpur being sent to it. ${ }^{114}$ Patel then turned to the Ministry of External Affairs (MEA) to approach Pakistan to accept 'the transfer of Meos from Hyderabad'. ${ }^{115}$ As the MEA was headed by 
Nehru himself, one wonders how Patel expected that ministry to oblige him. The Pakistan Government was not willing to allow them to enter that Dominion because they were 'Indian Musalmans' and the disillusioned Jamiat now approached the Governor-General C. Rajagopalachari, who forwarded this plea to B. G. Kher, premier Bombay, where the Hyderabad Meos had reached by that time. Kher approached Patel, who, again, assured repatriation but made no commitments about its location. Kher conveyed this open-ended assurance to Mohammad Mian on 17 December 1948. In the last days of 1948, these 6,500 Meos seemed en route to Pakistan. The Police Commissioner of Bombay confirmed that they did not intend going back to their native places, 'for fear of molestation'.. ${ }^{116}$ Patel, Shankar and the MoS clung to the Meos' unwillingness to return, the Matsya Union's unwillingness to accept them and their insistence that when 'in almost all other matters, Pakistan [had] been making Alwar and Bharatpur at par with East Punjab' then why not so 'for the purpose of permitting these Meos' to go there. ${ }^{117}$ They instructed the Bombay government that they were taking up the question with GOP and meanwhile the Meos were not to be sent to Alwar and Bharatpur. ${ }^{118}$

Eventually, on 21 January 1949, Subimal Dutt, the Commonwealth Secretary, attempted to confront Patel and reminded the MoS that there was a letter from Kher stating that 'Sardar Patel had promised to render every assistance for the rehabilitation of these refugees in their own homeland'. Moreover, Dutt insisted that there was 'no question of our making a reference to Pakistan at this stage' and claimed that Pakistan will refuse to receive so many Muslim refugees from India. ${ }^{119}$ The episode dragged on, with the Ministry of R\&R now siding with the MEA. Secretary C. N. Chandra noted that from Dutt's letter it was clear that Patel gave Kher to understand that every facility would be afforded to the 6,500 Meos in Bombay to return to Alwar and Bharatpur. Chandra also had a technical (and moral) point: 'since these Meos did not leave the Indian Dominion, I do not know whether we can refuse to 
rehabilitate them in their own homes'. ${ }^{120}$ The Deputy Prime Minister found a way out of this dilemma. While he dropped the question of approaching the Pakistan Government, he desired instead to give all facilities to those who wished to proceed to Pakistan 'to approach the Pakistan High-Commission/Permit Officer' and obtain a permit.. ${ }^{121}$ The Chief Secretary, Bombay, was accordingly instructed. ${ }^{122}$

Meanwhile, while the Matsya Union was fulfilling the commitment of rehabilitating the Meos in the thirty-three ear-marked villages, in addition to allotting 77,000 acres of land to Punjabi refugees, the East Punjab administration was slacking in allotting land to the displaced Meos. Consequently, a number of Meos were moving in the countryside of Gurgaon, Alwar and Bharatpur. With social workers like Vinoba Bhave, religious leaders like Maulavi Ibrahim, and, interested ministers like Bhola Ram touring, assuring and encouraging Meos 'to resettle in their deserted houses', the East Punjab Government's lack of action was tantamount to flouting New Delhi’s 'compact area' decision. An irked K.B. Lall was now suggesting 'substantially adding to the area reserved in the Matsya Union' for Meos. In the present situation, he did not see any possibility of refugees and Meos sharing the same village peacefully. Lall felt that 'if each and every' displaced Meo was allowed to return to his home, a large number of those who had gone to Pakistan would 'trek back to their lands'.. ${ }^{123}$ Instead Lall proposed another list of villages amounting to 21,013 acres in Alwar and 21,166 acres in Bharatpur for Meos' resettlement, while warning the MoS about the 'rapid infiltration' of Meos. Lall's complaint was forwarded to the East Punjab government and Patel himself sent a letter to Premier Bhimsen Sachar on 23 April 1949. He also approved Lall's proposal of the extra land for Meos with the proviso that 'care should be taken to ensure that the Meos settled in these villages are in no circumstances allowed to overflow into other areas' thereby giving rise to undesirable complications.. ${ }^{124}$ 


\section{Coda}

By April 1949, the situation on the ground was overtaking the permission on paper and some 27,000 Meos had made their way into Bharatpur, as Lall put it, 'without permits' and with the assistance of 'corrupt local police and Mahajans'. ${ }^{125}$ Almost exactly two years after they were forcibly removed from their homes, Meos were forcing their way back to their original holdings despite the resistance of the MoS and the Matsya Union administration. ${ }^{126}$ Much like their departure in March-April 1947, their arrival in March-April 1949 too was achieved in an 'unsatisfactory atmosphere'. In both years, the administrative arrangements were 'inadequate to hold the scales between the Meos, the Punjabi refugees and the Jats'.. ${ }^{127}$ And, like the many Gandhians who supported them in 1947, there was another Gandhian on the scene in 1949, Sudhir Ghosh. Appointed as a Deputy Rehabilitation Commissioner by Nehru, he was pushing for the 'wholesale restoration' of Meo holdings in Matsya Union... ${ }^{128}$

In the last meeting of the fact-finding committee, it was finally decided to acknowledge ground realities and trifurcate the solution to the Meos' problem. Land was to be 'reserved' for refugees, 'restored' to Meos and maintained 'vacant' for future settlement of either displaced Muslims or non-Muslim refugees. Original holdings were to be matched with their equivalent, rehabilitation was to be met with resettlement and, together, both were to contribute to the 'grow more food' campaign. As far as possible, these categories were to be made complementary and not conflictual. In case of a clash, 'compact' areas were to be created, with Meos to be settled in the interior tracts, with its brackish water, deep wells and light soil, while the refugees were to be settled on agricultural property. Of course, 'mixed communities' were not yet to be countenanced.- ${ }^{129}$

Two years from the summer of 1947, the process of the return of Meos to their homelands had begun. The Matsya Union had verified the claims of 6,329 Meos (3,016 from 
Alwar and 3,315 from Bharatpur), amounting to 70,220 acres (34,400 in Alwar and 35,820 in Bharatpur). In the villages ear-marked for them, 9,449 acres in Alwar and 4,567 acres in Bharatpur had been allotted, making it a total of 14,016 acres in the Matsya Union. In Gurgaon, Meos belonging to the district had been allotted 19,904 acres, of which possession had been taken to the extent of 19,039 acres. A total allotment of 11,635 acres had been made to the Meos of Matsya Union in Gurgaon district, of which physical possession had been taken to the extent of 5,193 acres. In Ferozepur Jhirka, possession of 4,808 acres had been taken out of 5,748 acres allotted. It was only in the Nuh tehsil, where the allotted area was 5,887 acres that barely any physical possession had been taken: 385 acres only.

As they were able to get back to their homelands or its adjoining areas, Meos of the Matsya Union were not inclined to go to Nuh, which was non-contiguous to Matsya. Gopilal Yadav, minister for R\&R in the Matsya Union in 1949, now sought to convince the 'official mind' in New Delhi that the resettlement of Meos and other Muslim landowners 'in their own villages' did not present any law and order problem. That concern was complicated by another: namely that evacuee lands had remained only partially utilised. Consequently, the population that turned against them two years previously, seemed willing to 'welcome' them. By their own actions, Meos had made restoration in their villages 'the more obvious course' because of the considerable number who had already gone there. To echo Mayaram, they were yet again resisting a regime. Moreover, in the neighbouring Gurgaon, under the order of the East Punjab government, 'all Muslims who had remained in the Indian Union were being given their own lands with effect from Kharif 1949' and the fact-finding committee thus recommended that, simultaneously, there would be a 'restoration of Meos and Muslim landowners recorded in the census of July 1948, even if they were returnees from Pakistan, and including Meos of Matsya Union, who had received temporary allotment in Gurgaon during Rabi 1948-49', 130 


\section{Conclusion}

Just when all clouds on the official horizon seemed to be clearing, it was decided that the Matsya Union was to be integrated with the United State of Rajasthan on 15 May 1949.. ${ }^{131}$ Any recommendation regarding the resettlement of the Meos had to henceforth go to Jaipur. The unaware Meos had to brace for a battle during 1949-50 with yet another layer of the state. Their return was not smoothened, only splintered. They had survived the old Alwar and Bharatpur princely states and 'the killing fields' of Partition but paying 'the price of survival' to the post-1947 bureaucracies had arguably bruised them much more. ${ }^{132}$ The Meos had returned but as Gyanendra Pandey put the question perspicaciously: could 'a Muslim really be an Indian' at the altar of normative Hindu belonging, deserving of life and redistribution of resources? ${ }^{133}$ The bureaucratic mind could certainly not fathom the liminality of the Meos' and it could therefore not factor their re-territorialisation. Pandey's observations are to the point: there was not just 'a bureaucratic imperative at work...but a nationalist imperative as well'. 134 The Prime Minister himself put it well:

Our whole organisation has been built up with a view to helping the vast +mass of Hindu and Sikh refugees...It is not conditioned to look after Muslims whose cases stand on a somewhat different footing...there is not too much sympathy for these Muslim families among government departments or outside.... 135

It would take some more administrative organisation and sanitisation of 'state violence', ${ }^{136}$ before the Meos would be re-placed and no longer dis-placed. This would mean 
more of the tensions recorded in this article, namely of conflicting perspectives within the government establishment, with the Prime Minister stymied by his stalling Deputy, the limited influence of empathetic Gandhian activists over their 'official' interlocutors, and the then-prevailing competitive, communalised environment. The post-partition Indian nationstate tried to contain this environment by determining a separate if unequal certainty, wherever it found itself ranged against a pre-partition society; whether in Hyderabad or Mewat. The question of 'Muslim belonging in secular India' emerged, as shown by Taylor Sherman in the case of Hyderabad, not only amidst communal violence or refugee rehabilitation but an assertion of 'majority rule', first through 'government service' and, later, electoral democracy. ${ }^{137}$ In Mewat, to Nehru, 'what was done to the Meos' did not seem to be 'any concession at all'. The Prime Minister lamented that there was 'a great deal of loose talk about a secular state. What that means, few people seem to understand'. ${ }^{138}$ As he put it, Muslims in India had 'no particular rights except what we, out of our grace, might grant them'.. ${ }^{139} \mathrm{He}$ understood the need to 'be strict about the return of large number of Muslims to India from Pakistan', appreciated that psychologically refugees were 'irritated by even a single instance... after the violence of the post-partition days', and admitted that it was 'difficult to apply any strict legal test' but, 'viewed with dismay and sorrow the narrow and communal outlook' that accompanied these sentiments, and which had progressively grown and showed itself in Mewat.. ${ }^{140}$

This article partakes in the ongoing shifts in the study of late-1940s in India and exposes the cracks between the two periods of partition and democracy. It has sought to juxtapose the 'high politics' and elite bureaucratic understandings that permeated the state on the one hand, and contrasted it with the expectations of the Meos, their idealist sympathisers and their response to the experience of violence. From the prelude to Partition to its long aftermath, the old liminal socio-cultural existence of the Meos was compromised by the 
taxonomies of the political institutions of the new Indian nation-state. The nation's search for stability, security and consolidation was catastrophic for the Meos. While the process of state re-formation and subject re-creation was on its way, simultaneously and as a consequence, another passage of ruination and parochialisation of critical segments of society was also set in motion; indeed, the former fed the latter. Partition's afterlife in Mewat rendered intercommunity relations perilous and they also severely compromised discourse between state and society. This denouement redefined the Meos' new status and habitus, reduced their socio-political existence and removed their broader cultural resonances. It might be historiographically reductive to speak of the long shadow of collective memories of these events in the region today as a reason for the continuing violence against Meos in recent times. ${ }^{141}$ But it would not be reductive to draw comparisons in the script of the post-partition Indian nation-state as it dealt with the complex social constitution of its citizens during a period of crisis and the taxonomies by which the 'secular state' labels 'minorities; and continues to question and parse their rights of belonging and identification in India.

\section{References}

Bandyopadhyay, S. Decolonization in South Asia: Meanings of Freedom in Postindependence West Bengal, 1947-52, London, 2009.

Basu, A. Mridula Sarabhai: Rebel with a Cause, Delhi, 1996.

Bharadwaj, S. 'Migration, Mobility and Memories: Meos in the Processes of Peasantisation and Islamisation in Medieval Period', Indian Historical Review, Vol. 39, Issue 2 (2012), pp. 217-250.

Bharadwaj, S. Contestations and Accommodations: Mewat and Meos in Mughal India, Delhi, 2016. 
Brass, P. The Production of Hindu-Muslim Violence in Contemporary India, Washington, 2015.

Choudhary, V. ed. Dr. Rajendra Prasad: Correspondence and Select Documents, Vol. 9, Delhi, 1987.

Copland, I. 'The Further Shores of Partition: Ethnic Cleansing in Rajasthan in 1947', Past and Present, No. 160 (1998), pp. 203-39.

Copland, I. State, Community and Neighbourhood in Princely North India, c. 1900-1950, Basingstoke, 2005.

Das, D. ed., Sardar Patel's Correspondence, 1945-50, Vol. V, Ahmedabad, 1973.

De, R. A People's Constitution: The Everyday Life of Law in the Indian Republic, Princeton, 2018.

Geva, R. 'The Scramble for Houses: Violence, a factionalised State, and informal economy in post-partition Delhi', Modern Asian Studies, Vol. 51, No. 3 (May 2017), pp. 769-824.

Gopal, S. ed., Selected Works of Jawaharlal Nehru, Series II Vol. IV, Delhi, 1973.

Gould, W. Bureaucracy, Community and Influence: Society and the State in India, 19301960s, London, 2011.

Jalal, A. The Pity of Partition: Manto's Life, Times, and Work across the India-Pakistan Divide, New Jersey, 2013.

Khan, Y. 'Performing Peace: Gandhi's assassination as a critical moment in the consolidation of the Nehruvian state', Modern Asian Studies, Vol. 45, No. 1 (January 2011), pp. 57-80. Kruger, H. ed., Kunwar Mohammad Ashraf: An Indian Scholar and Revolutionary (19031962), Berlin, 1966.

Kumar, M. 'Cow Veneration among Meo Muslims of Mewat Presents the Complex Nature of Religious Identities', Economic and Political Weekly, Vol. 54, Issue No. 1 (05 January 2019) 
Kumar, M. 'The Art of Resistance: The Bards and Minstrels' Response to AntiSyncretism/Anti-liminality in north India', Journal of the Royal Asiatic Society, Vol. 29, Issue 2 (April 2019), pp. 219-247.

Kudaisya, G. A Republic in the Making: India in the 1950s, Delhi, 2017.

Kudaisya, G. Reorganisation of States in India: Text and Context, Delhi, 2014.

Kudaisya, M. “"A Mighty Adventure”: Institutionalising the Idea of Planning in Post-colonial India, 1947-60', Modern Asian Studies, Vol. 43, No. 4 (July 2009), 939-978.

Mayaram, S. Resisting Regimes: Myth, Memory and the Shaping of a Muslim Identity, Delhi, 1997.

Mayaram S. Against History, Against State: Counterperspectives from the Margins, New York, 2004.

Mayaram, S. 'Belonging/Unbelonging to the Nation' in Tripathi, R. C. and Purnima Singh eds., Perspectives on Violence and Othering in India, Delhi, 2016, pp. 71-83.

Mishra, S. Nishkam Karamyogi: Pandit Sunder Lal, Delhi, 2014.

National Archives of India (NAI), New Delhi, Ministry of States (MoS).

Nehru Memorial Museum and Library (NMML), New Delhi, Pandit Sunder Lal Papers. Nehru Memorial Museum and Library (NMML), New Delhi, N. B. Khare Oral Transcript (310).

Nehru Memorial Museum and Library (NMML), New Delhi, Jawaharlal Nehru Papers.

Pandey, G. Remembering Partition: Violence, Nationalism and History in India, Oxford, 2001.

Pandey, G. Routine Violence: Nations, Fragments, Histories, Stanford, 2006.

Pandey, G. 'Can a Muslim be an Indian?', Comparative Studies in Society and History, Vol. 41, No. 4 (October 1999), pp. 608-629. 
Prakash, G., N. Menon and M. Laffian, eds., The Postcolonial Moment in South and Southeast Asia, London, 2018.

Schroeder, Paul. 'History and International Relations Theory: Not Use or Abuse, But Fit or Misfit', International Security, Vol. 22, Issue 1 (1997), pp. 64-74.

Sen, U. Citizen Refugee: Forging the Indian Nation after Partition, Cambridge, 2018.

Shani, O. How India Became Democratic: Citizenship and the Making of the Universal Franchise, Cambridge, 2017.

Sherman, T. C. State violence and punishment in India, 1919-1956, London, 2009.

Sherman, T. C. 'From "Grow More Food" to "Miss a Meal": Hunger, Development and the Limits of Post-Colonial Nationalism in India, 1947-1947', South Asia: Journal of South Asian Studies, Vol. 36, Issue 4 (2013), pp. 571-588.

Sherman, T. C., W. Gould, and S. Ansari, eds., From Subjects to Citizens: Society and the Everyday State in India and Pakistan, 1947-1970, Cambridge, 2014.

Sherman, T. C. Muslim Belonging in Secular India: Negotiating Citizenship in Postcolonial Hyderabad, Cambridge, 2015.

Siddiqi, M. 'History and Society in a Popular Rebellion: Mewat, 1920-1933', Comparative Study of Society and History, Vol. 28, Issue 3 (July 1986), pp. 442-467.

Siegel, B. Hungry Nation: Food, Famine and the Making of Modern India, Cambridge, 2018. Talbot, I. and G. Singh The Partition of India, Cambridge, 2009.

Tan, T. Y. and G. Kudaisya The Aftermath of Partition in South Asia, London, 2000.

Tan, T. Y. and G. Kudaisya Partition and Post-Colonial South Asia, London, 2007.

Tennyson, H. India's Walking Saint: The Story of Vinoba Bhave, New York, 1955.

Tyabji, N. Forging Capitalism in Nehru's India: Neocolonialism and the State, c. 1940-1970, Delhi, 2015.

Virdee, P. From the Ashes of 1947: Reimagining Punjab, Cambridge, 2017. 
Zamindar, V. F.Y. The Long Partition and the Making of Modern South Asia: Refugees, Boundaries, Histories, New York, 2007.

\section{Notes}

${ }^{1}$ See, for an analysis connecting Partition violence with Nationalism history in India, Pandey, Remembering Partition, pp. 21-66.

${ }^{2}$ See, for an earlier historiographical overview, Talbot and Singh, The Partition of India, pp. 7-24 and, for a recent iteration, Pippa Virdee, From the Ashes of 1947, pp. 2-19.

${ }^{3}$ See Tan and Kudaisya, The Aftermath of Partition in South Asia and Partition and Postcolonial South Asia, De, A People's Constitution, Medha Kudaisya, “"A Mighty Adventure”, Shani, How India Became Democratic, and, Kudaisya, A Republic in the Making and Reorganisation of States in India.

${ }^{4}$ Sherman, Gould and Ansari, eds., From Subjects to Citizens, Prakash, Menon and Laffian, eds., The Postcolonial Moment in South and Southeast Asia, Siegel, Hungry Nation, Sen, Citizen Refugee and Tyabji, Forging Capitalism in Nehru's India.

${ }^{5}$ Mayaram, Resisting Regimes, p. 208 and Copland, 'The Further Shores of Partition', p. 216.

${ }^{6}$ Mayaram, Resisting Regimes, p. 162.

${ }^{7}$ Copland, 'The Further Shores of Partition', p. 203.

${ }^{8}$ See Mayaram, Resisting Regimes.

${ }^{9}$ See Bharadwaj, 'Migration, Mobility and Memories'.

${ }^{10}$ See Kumar, 'Cow Veneration among Meo Muslims of Mewat' and 'The Art of Resistance'.

${ }^{11}$ See Siddiqi, 'History and Society in a Popular Rebellion'.

${ }^{12}$ See chapters 2 and 5 of Mayaram, Against History, Against State. 
${ }^{13}$ Bandyopadhyay, Decolonization in South Asia, p. 1.

${ }^{14}$ See Sherman, State violence and punishment in India, Gould, Bureaucracy, Community and Influence and Pandey, Routine Violence.

${ }^{15}$ See Jalal, The Pity of Partition.

${ }^{16}$ Nehru Memorial Museum and Library (henceforth NMML), Oral Transcript, NB Khare, Acc. No. 310, p. 73.

${ }^{17}$ Schroeder, 'History and International Relations Theory', p. 65.

${ }^{18}$ Sunder Lal (1886-1980), a close associate of Gandhi, was involved in the enquiry of Kanpur riots (1931), promotion of a composite Hindustani language and culture (1946) and the goodwill mission to investigate the violent aftermath of Hyderabad's accession to India (1948). See Mishra, Nishkam Karamyogi.

${ }^{19}$ On Gandhi's associates, Vinoba Bhave (1895-1982), see Tennyson, India's Walking Saint and on Mridula Sarabhai (1911-1974), see Basu, Mridula Sarabhai.

${ }^{20}$ National Archives of India (henceforth NAI), Ministry of States (henceforth MoS), File No. 2 (6)-PR/47, Khare to Patel (D-700-PR/47), 18 August 1947.

${ }^{21}$ NAI, MoS, File No. F.8 (2)-R/49, C Ganesan's note, 5 May 1949.

22 Pandey, 'Can a Muslim be an Indian', pp. 610-11, 626.

${ }^{23}$ Mayaram, 'Belonging/Unbelonging to the Nation', p. 72.

${ }^{24}$ See Bharadwaj, 'Migration, Mobility and Memories' and Bharadwaj, Contestations and Accommodations.

${ }^{25}$ Mayaram, 'Belonging/Unbelonging to the Nation', p. 72. See Mayaram, Resisting Regimes.

${ }^{26}$ See Copland, State, Community and Neighbourhood in Princely North India, pp. 68-167

${ }^{27}$ Pandey, 'Can a Muslim be an Indian', pp. 614-15. 
${ }^{28}$ Mayaram, 'Belonging/Unbelonging to the Nation', pp. 73-77. On Ashraf see, Horst

Kruger, ed., Kunwar Mohammad Ashraf.

${ }^{29}$ NMML, Pandit Sunder Lal Papers, File No. 3, Evangeline Ingram's note titled 'Short History of the Meos'.

${ }^{30}$ NMML, Pandit Sunder Lal Papers, File No. 3, Bhargava to Secretary, 'Phir Basao' Committee, undated.

${ }^{31}$ NMML, Pandit Sunder Lal Papers, File No. 3, letters from the above-named and others, 22 March-18 April 1948.

${ }^{32}$ NMML, Pandit Sunder Lal Papers, File No. 3, report by Lal and Bhargava, 11 April 1948.

${ }^{33}$ Mayaram, 'Belonging/Unbelonging to the Nation', p. 75.

${ }^{34}$ NMML, Pandit Sunder Lal Papers, File No. 3, report by Lal and Bhargava, 11 April 1948.

${ }^{35}$ NMML, Pandit Sunder Lal Papers, File No. 3, report by Munshi Malik, 18-19 April 1948.

${ }^{36}$ Pandey, 'Can a Muslim be an Indian?' pp. 613-14.

${ }^{37}$ See Geva, 'The Scramble for Houses'.

${ }^{38}$ See Zamindar, The Long Partition and the Making of Modern South Asia.

${ }^{39}$ See Siddiqi, 'History and Society in a Popular Rebellion'.

${ }^{40}$ NMML, Pandit Sunder Lal Papers, File No. 3, Khan's note, 26 May 1948.

${ }^{41}$ NMML, Pandit Sunder Lal Papers, File No. 3, Evangeline Ingram's note titled 'Short History of the Meos'.

${ }^{42}$ NMML, Jawaharlal Nehru Papers, File No. 4, Nehru to Patel, 3 December 1947.

${ }^{43}$ India Office Records (British Library), L/P\&J/7/12589, R. C. Hadow's report on his visit to Alwar. Cited in Pandey, 'Can a Muslim be an Indian?' p. 628, footnote 30.

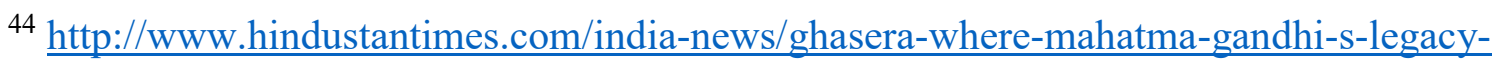
lives-on-waits-for-india/story-I8Z0XY4IrAW07aIc3pw48I.html (accessed 7 November 2017). 
${ }^{45}$ Khan, 'Performing Peace', p. 58

${ }^{46}$ ibid., pp. 60-61.

${ }^{47}$ NMML, Pandit Sunder Lal Papers, File No. 3, report by Lal and Bhargava, 11 April 1948.

${ }^{48}$ Khan, 'Performing Peace', p. 60.

${ }^{49}$ NMML, Pandit Sunder Lal Papers, File No. 3, report by Lal and Bhargava, 11 April 1948.

${ }^{50}$ NMML, Pandit Sunder Lal Papers, File No. 3, Khan to Bhave, undated.

${ }^{51}$ NMML, Pandit Sunder Lal Papers, File No. 3, Ingram's note on the 'present situation in Mewat', 4 May 1948.

${ }^{52}$ NAI, MoS, File No. F.8 (14)-G (R)/48, Seth to MK Vellodi, No. 467-FR, 27 February 1948.

${ }^{53}$ NAI, MoS, File No. F.8 (14)-G (R)/48, Seth to VD Dantyagi, No. 476-FR, 27 February 1948.

${ }^{54}$ NAI, MoS, File No. F.8 (14)-G (R)/48, Dantyagi to Ganesan, 2 March 1948.

${ }^{55}$ NAI, MoS, File No. F.8 (14)-G (R)/48, Zaidi to Nehru, 4 March 1948.

${ }^{56}$ NAI, MoS, File No. F.8 (14)-G (R)/48, Sapru to Vellodi, No. 216-AD, 6 March 1948.

${ }^{57}$ NAI, MoS, File No. F.8 (14)-G (R)/48, petitions to Nehru, 18 March 1948.

${ }^{58}$ NAI, MoS, File No. F.8 (14)-G (R)/48, MK Kirpalani to Sapru and Seth, 20 March 1948.

${ }^{59}$ NAI, MoS, File No. 12 (52)-P/48, Ranbir Singh to Patel, 16 March 1948.

${ }^{60}$ NAI, MoS, File No. 12 (52)-P/48, Seth to MK Kirpalani, DO No. 73 and HK Tandon to DC (Gurgaon), 25 March 1948.

${ }^{61}$ NAI, MoS, File No. 12 (52)-P/48, Gopal Das to Seth, 19 March 1948.

${ }^{62}$ NAI, MoS, File No. 12 (52)-P/48, Seth to MK Kirpalani, 420/6-AD/48 and S Narayanswamy (MoS) to CS (East Punjab), 28 March 1948 and MR Sachdeva (EC, East Punjab) to DC (Gurgaon), 6 April 1948.

${ }^{63}$ See chapter 6 of Mayaram, Against History, Against State. 
${ }^{64}$ NAI, MoS, File No. 8 (30)-G (R)/48, from Alwar to MoS, DO No. 136/Cen, 16 April 1948.

${ }^{65}$ NAI, MoS, File No. 8 (30)-G (R)/48, SP and Nazim (Mundawar) to DM (Alwar), 10-11 April 1948.

${ }^{66}$ On 'blame displacement', see Brass, The Production of Hindu-Muslim Violence in Contemporary India.

${ }^{67}$ NAI, MoS, File No. 8 (30)-G (R)/48, note in the R\&R, 28 April 1948.

${ }^{68}$ NAI, MoS, File No. 8 (30)-G (R)/48, note in the MoS, 30 April 1948.

${ }^{69}$ Das, ed., Sardar Patel's Correspondence, Patel to Trehan, 16 July 1947, p. 289.

${ }^{70}$ NAI, MoS, File No. F.8 (14)-G (R)/48, MK Kirpalani to Seth and Sapru, 15 April 1948.

${ }^{71}$ Mayaram, 'Belonging/Unbelonging to the Nation', pp. 71-72, 78.

${ }^{72}$ NAI, MoS, File No. F.8 (14)-G (R)/48, MK Kirpalani to Sarabhai, 27 April 1948.

${ }^{73}$ NAI, MoS, File No. F.8 (14)-G (R)/48, KB Lall to Kirpalani, 14 May 1948.

${ }^{74}$ NAI, MoS, File No. F.8 (14)-G (R)/48, Trivedi to Nehru, DO No. 486/GEP, 10 May 1948.

${ }^{75}$ NAI, MoS, File No. F.8 (14)-G (R)/48, SK Kirpalani to VP Menon, DO No. 489/R/36-S, 11 May 1948.

${ }^{76}$ NAI, MoS, File No. F.8 (14)-G (R)/48, Shankar's note about Patel's meeting of 17-18 May, 22 June 1948.

${ }^{77}$ NAI, MoS, File No. F.8 (14)-G (R)/48, Dharma Vira (PMS) to MK Kirpalani, D/S/2325, 21 May 1948.

${ }^{78}$ NAI, MoS, File No. F.8 (14)-G (R)/48, Kirpalani to Vira, 27 May 1948.

${ }^{79}$ NAI, MoS, File No. F.8 (14)-G (R)/48, C Ganesan’s note, 31 May 1948.

${ }^{80}$ NAI, MoS, File No. F.8 (14)-G (R)/48, Ashfaque Hussain to Menon, 3 June 1948.

${ }^{81}$ NAI, MoS, File No. F.8 (14)-G (R)/48, Neogy's summary of his conversation with Patel, 4 June 1948. 
${ }^{82}$ NAI, MoS, File No. F.8 (14)-G (R)/48, Kirpalani's note, 23 June 1948.

${ }^{83}$ NAI, MoS, File No. F.8 (14)-G (R)/48, Lall to MK Kirpalani, 20 June 1948.

${ }^{84}$ NAI, MoS, File No. F.8 (14)-G (R)/48, Kirpalani's note, 23 June 1948.

${ }^{85}$ On 'grow more food' campaign, see Sherman, 'From "Grow More Food” to "Miss a Meal"”.

${ }^{86}$ NAI, MoS, File No. F.8 (14)-G (R)/48, Lall to CN Chandra, 20 June 1948.

${ }^{87}$ NAI, MoS, File No. F.8 (14)-G (R)/48, minutes of the meeting of the JRB, 25 June 1948.

${ }^{88}$ NMML, Jawaharlal Nehru Papers, File No. 10, Nehru to Saksena, 26 June 1948.

${ }^{89}$ NAI, MoS, File No. F.8 (14)-G (R)/48, Shankar's note, 26 June 1948 and MK Kirpalani to Lall, 28 June 1948.

${ }^{90}$ NAI, MoS, File No. F.8 (14)-G (R)/48, telegram to Patel from Kallu and Badlu, undated.

${ }^{91}$ NAI, MoS, File No. F.8 (14)-G (R)/48.

${ }^{92}$ NAI, MoS, File No. F.8 (14)-G (R)/48, Lall to VP Menon, P.IV-26/48, 26 July 1948.

${ }^{93}$ NMML, Jawaharlal Nehru Papers, File No. 11 (Pt.-I), Nehru to Rajagopalachari, 13 July 1948.

${ }^{94}$ NAI, MoS, File No. F.8 (14)-G (R)/48, Nehru to Ayyangar, No. 1126-PM, 5 August 1948.

${ }^{95}$ NAI, MoS, File No. F.8 (14)-G (R)/48, Rao to Nehru, 4 August 1948.

${ }^{96}$ NAI, MoS, File No. F.8 (14) - G (R)/48, Patel's note, No. XV-(17)/48, 24 August 1948.

${ }^{97}$ Quoted in Pandey, 'Can a Muslim be an Indian?’ p. 627.

${ }^{98}$ NAI, MoS, File No. F.8 (14) - G (R)/48, Patel's note, No. XV-(17)/48, 24 August 1948.

${ }^{99}$ NAI, MoS, File No. F.8 (14)-G (R)/48, Dantyagi to VP Menon, 18 September 1948.

${ }^{100}$ NAI, MoS, File No. F.8 (14)-G (R)/48, 15 September 1948.

${ }^{101}$ NAI, MoS, File No. F.8 (14)-G (R)/48, minutes of the meeting of the JRB, 24 September 1948.

102 NAI, MoS, File No. F.8 (14)-G (R)/48, Lall to Ganesan, 3 October 1948. 
${ }^{103}$ NAI, MoS, File No. F.8 (14)-G (R)/48, Shankar's note, 4 October 1948.

${ }^{104}$ NAI, MoS, File No. F.8 (14)-G (R)/48, Dantyagi to Lall, 9 November 1948 and note in the R\&R, 13 November 1948.

${ }^{105}$ NAI, MoS, File No. F.8 (14)-G (R)/48, Lall to Dantyagi, 24 November 1948.

${ }^{106}$ NAI, MoS, File No. F.8 (14)-G (R)/48, Tara Chand to Lall, 7 December 1948.

${ }^{107}$ NAI, MoS, File No. F.8 (14)-G (R)/48, Lall to Tara Chand, 19 December 1948.

${ }^{108}$ Copland, State, Community and Neighbourhood in Princely North India, p. 165.

${ }^{109}$ Choudhary, ed., Dr. Rajendra Prasad, Patel to Prasad, 24 June 1948, p. 153.

${ }^{110}$ NAI, MoS, File No. F.8 (14)-G (R)/48, Chaudhuri to Vellodi, DO No. JNC/48/156, 8 November 1948.

${ }^{111}$ NAI, MoS, File No. F.8 (14)-G (R)/48, Ganesan's note, 17 November 1948.

${ }^{112}$ NAI, MoS, File No. F.8 (14)-G (R)/48, 18 November 1948.

${ }^{113}$ NAI, MoS, File No. F.8 (14)-G (R)/48, Mohammad Mian to Patel, No. Meos-1442/48, 22 November 1948.

${ }^{114}$ NAI, MoS, File No. F.8 (14)-G (R)/48, Dantyagi's and other's notes, 19, 22 and 23 November 1948.

${ }^{115}$ NAI, MoS, File No. F.8 (14)-G (R)/48, CN Chandra's note, 8 December 1948.

${ }^{116}$ NAI, MoS, File No. F.8 (14)-G (R)/48, JS Bharucha to VT Dehejia (HS, Bombay), No.

11698/M, 27 December 1948.

${ }^{117}$ NAI, MoS, File No. F.8 (14)-G (R)/48, Shankar's note, 30 December 1948.

${ }^{118}$ NAI, MoS, File No. F.8 (14)-G (R)/48, MoS to HS, Bombay, 19 January 1949.

${ }^{119}$ NAI, MoS, File No. F.8 (14)-G (R)/48, Dutt to NM Buch, DO No. D.666/49-PakII), 21

January 1949.

${ }^{120}$ NAI, MoS, File No. F.8 (14)-G (R)/48, Chandra's note, 24 January 1949.

${ }^{121}$ NAI, MoS, File No. F.8 (14)-G (R)/48, Shankar's note, 15 February 1949. 
${ }^{122}$ NAI, MoS, File No. F.8 (14)-G (R)/48, HL Soni to CS, Bombay, (F.8 (2)-R/49), 4 May 1949.

${ }^{123}$ NAI, MoS, File No. F.8 (14)-G (R)/48, Lall to Ganesan, 11 February 1949.

${ }^{124}$ NAI, MoS, File No. F.8 (14)-G (R)/48, Shankar's note, 9 March 1949 and MoS to Lall, 17 March 1949.

${ }^{125}$ NAI, MoS, File No. F.8 (2)-R/49, Lall to MoS, 17 April 1949.

${ }^{126}$ NAI, MoS, File No. F.8 (2)-R/49, AB Chatterjee's note, 28 April 1949.

${ }^{127}$ NAI, MoS, File No. F.8 (2)-R/49, Lall to Chatterjee, 30 April 1949.

${ }^{128}$ NAI, MoS, File No. F.8 (2)-R/49, Ghosh to Chatterjee, DO. No. RHA (502) 78, 13 May 1949.

${ }^{129}$ NAI, MoS, File No. F.8 (2)-R/49, Lall to Ghosh, 30 April 1949.

${ }^{130}$ NAI, MoS, File No. F.8 (2)-R/49, final report of the Fact-Finding Committee, 24 April 1949.

${ }^{131}$ NAI, MoS, File No. F.8 (2)-R/49, Chatterjee's note, 13 May 1949.

${ }^{132}$ Copland, State, Community and Neighbourhood in Princely North India, p. 144, 160

${ }^{133}$ Pandey, 'Can a Muslim be an India?' p. 614.

${ }^{134}$ ibid., p. 629

${ }^{135}$ NMML, Jawaharlal Nehru Papers, File No. 23 (Pt.-II), Nehru to Saksena, 31 May 1949.

${ }^{136}$ Mayaram, Resisting Regimes, pp. 203-07.

${ }^{137}$ See Sherman, Muslim Belonging in Secular India.

${ }^{138}$ NMML, Jawaharlal Nehru Papers, File No. 24 (Pt.-II), Nehru to Khanna, 6 June 1949.

139 ibid.

140 ibid.

${ }^{141}$ See the media coverage of Pehlu Khan's lynching in April 2017. 